\title{
Innovation in Emerging Markets: The Case of Latin America
}

\section{Emerging Multinationals Research Network (EMRN)}

Lourdes Casanova, Cornell University, USA

Fernanda Cahen, University of Southern California, USA, and Centro Universitario FEl, Brazil

Anne Miroux, Cornell University, USA

Diego Finchelstein, Universidad de San Andrés/Conicet, Argentina

Anabella Davila, Tecnológico de Monterrey, Mexico

Juana García, Universidad de los Andes, Colombia

Veneta Andonova, Universidad de los Andes, Colombia

Moacir Miranda de Oliveira Jr., Universidade de São Paulo, Brazil

\section{Introduction}

In the past 15 years, emerging markets have come to represent about half of global Gross Domestic Product (GDP). Led by China, they have made gains in economic development as well as political influence; in turn, their companies have taken on a new level of importance in driving innovation, local development, and global competition (Casanova \& Miroux, 2018). Thus, we discuss the drivers, types and outcomes of innovation in emerging markets, with a focus on Latin America. The Emerging Multinationals Research Network (EMRN) has undertaken a number of case studies, collaborations with the Emerging Markets Institute (EMI), and a survey-based research study on this issue, building on discussions at AIB-LAT conferences in Santiago de Chile (2015), São Paulo (2016), Lima (2017) and Buenos Aires (2018). This work on innovation is being compiled in a forthcoming book by Cambridge University Press entitled From Copycat to Leaders: Innovation from Emerging Markets. This article sets out some of the issues to be dealt with in the forthcoming book (Cahen, Casanova, \& Miroux, 2019).

From the turn of the century to 2015, Latin America has witnessed a profound economic and social transformation, which has significantly impacted the creation and flow of technology as well as innovation in the region. Pro-market reforms and a decade of economic growth has fostered the expansion of consumer markets and elevated most economies to middle and upper-middle-income status. This scenario ushered in a business environment increasingly attractive for multinational companies. It also contributed to the rise of Latin American multinationals - multilatinas (Andonova \& Losada-Otalora, 2017).

Following a decline in commodity prices and corruption scandals, market turbulence in Argentina, recession in Brazil, and a continued political deterioration in Venezuela, economic growth in the region slowed down between 2016-2018. The region grew by $0.6 \%$ in 2018 and is expected to grow $1.6 \%$ in 2019. Despite these challenges, certain areas in Latin America have developed a business-friendly environment with resilient ecosystems that seem to resist the political and economic instability (Oliveira Jr., Cahen \& Borini, 2019). Examples include the São Paulo state in Brazil in banking, information technology (IT) and aeronautics; Guadalajara in Mexico in IT; Santiago in Chile in knowledge intensive services; or Bogotá and Medellín in Colombia in banking and services. Some multilatinas have become global innovative leaders, such as the 
bus manufacturer Marcopolo, and cosmetics company Natura from Brazil, building materials firm Cemex, bakery manufacturer Grupo Bimbo and IT company Softtek from Mexico (Casanova, 2009), steel manufacturer Techint and ecommerce firm MercadoLibre from Argentina, and LATAM airlines from Chile.

Typically, many of these companies have played a modest role in global innovation, but some have been successfully developing their own capabilities on this front (Amann \& Cantwell, 2012). These include large multilatinas that have been thriving amidst global competition, but also an increasing number of innovative entrepreneurial companies and digital unicorns (as of 2019 there are around ten in the region, nine of them in technology). Increasing connectivity, brought about by internet dissemination and mobile telephony, has fostered unprecedented business opportunities for innovative small companies in e-commerce, digital services, and digital platforms (Cahen \& Oliveira Jr., 2018).

Drawing on examples from Latin America, this article explores how innovation contributes to the region's economic growth. It features new types, mechanisms and conditions for innovation: the relevance of the institutional environment, the impact of innovation on social development, and the "catchup" dynamics in the region.

\section{From Copycat to Leaders: Innovation from Emerging Markets}

Prominent studies on innovation have typically focused on technology-driven and R\&D-based innovation, analyzing mostly patent applications and intellectual property. Such studies essentially have been based on the experiences of multinationals from developed countries (DMNEs). Traditionally, DMNEs first developed and commercialized innovations at home and in a second stage set up subsidiaries to introduce them in emerging countries. Over the last two decades, however, the origin and direction of innovation flows has significantly changed, with many examples of products first introduced in emerging countries.

The literature on innovation does not discuss much the particular drivers and agents of innovation in emerging markets. For example, R\&D-based innovation in developed countries tends to rely heavily on the private sector; however, the private sector in emerging markets faces significant financial and institutional constraints. Hence, the public sector, and sometimes the military, play a key role in this type of innovation despite small public budgets. In some cases, state-owned firms and agencies are a key driver in $\mathrm{R} \& \mathrm{D}$ and innovation. In addition, the success of innovative companies often also depends on the efforts of other innovators and on relationships with other ac- tors (such as research institutions, governments, etc.) within their innovation ecosystems.

In emerging markets, fast economic growth and integration into the global economy often coexist with institutional voids, limited public spending, poor governance, corruption, poverty, and inequality. This context leads to alternative drivers of innovation. For instance, the Argentine software developer Globant took advantage of the high-quality of human capital available in the country and the conditions prevailing in the country in the wake of a large economic crisis to build one of the most dynamic unicorns in the region. Likewise, driven by the need to answer the basic needs of the population in resource-scarce societies, companies, mainly from Asia as well as Latin America and Africa, have been developing new products and services that are considerably less expensive than in developed countries. A variety of terms have been coined to date to refer to such innovations like low-cost, frugal, social, and bottom-of-the-pyramid innovation, etc.

Most studies exploring innovation in emerging markets describe a very incipient process based on imitation (copycats) with only a few more sophisticated organizational capabilities pointing at organic innovation. In our analysis, we follow the broad (and relatively widely accepted) definition of innovation that includes not only technology and R\&D-based innovation but also new organizational and production processes and business models. We pay particular attention to knowledge transfers from emerging economies (reverse innovation), and new types of innovation such as frugal innovation.

Based on the literature, our framework of analysis (see Figure 1) establishes a taxonomy of different drivers, types, and outcomes of innovation in emerging markets.

\section{Innovation in Latin America}

The following sections focus on the drivers, types, and outcomes of innovation in Latin America.

\section{Drivers of Innovation}

- Institutional challenges: These challenges increase transaction costs and operational constraints for local companies. As a result, innovation and internationalization in key sectors are typically shaped by strong government involvement (Finchelstein, 2017), or undertaken by state-owned companies. Governments in Latin America also act as strategic investors in public labs and private companies to foster innovation. Still, public and private spending as a percentage of GDP remain small.

- Social demands: Latin American countries suffer from social inequality and poverty. While these are major operational challenges for local companies, they can also serve as busi- 
Figure 1. Drivers, types, and outcomes of innovation in emerging markets

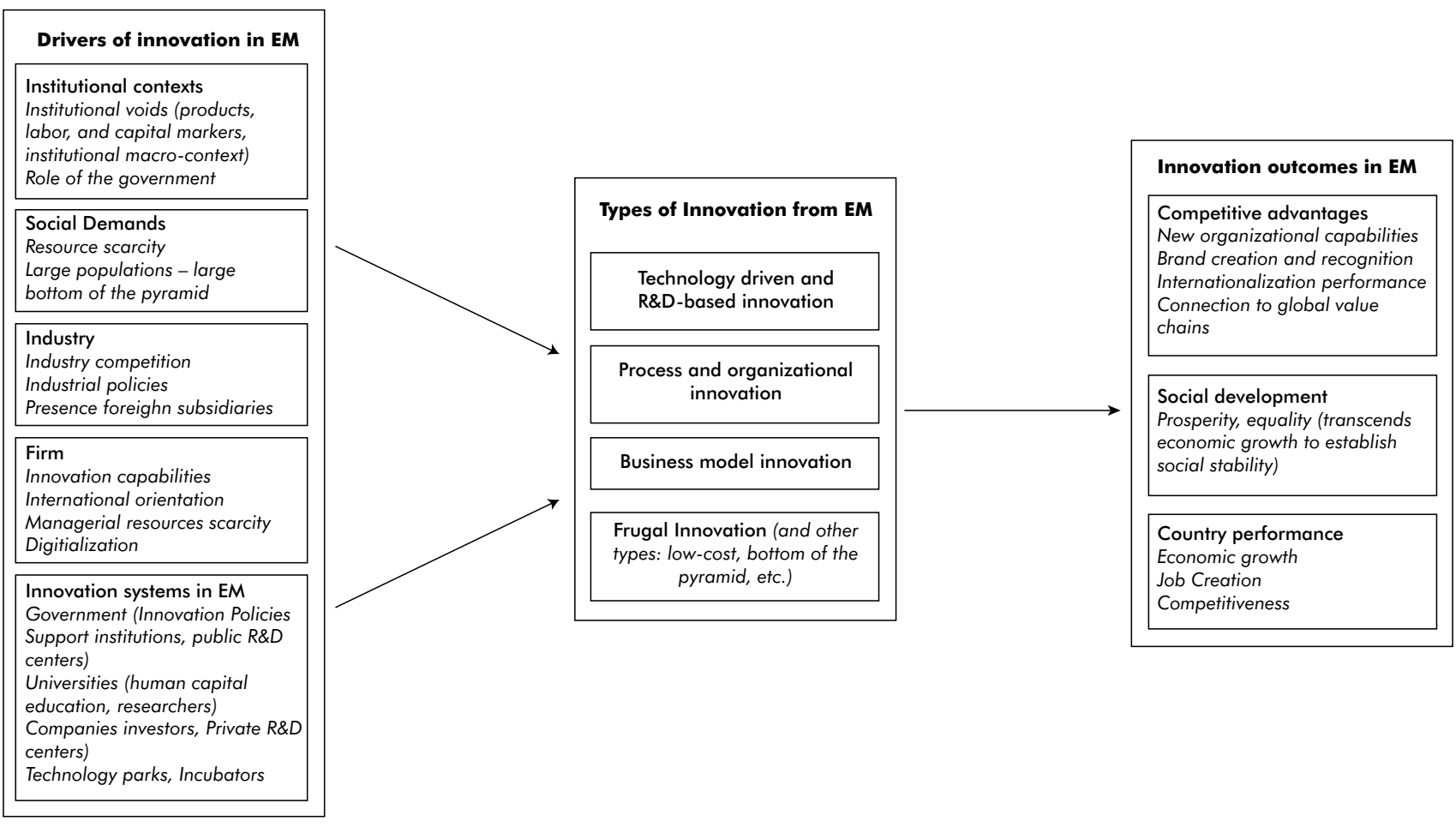

ness opportunities for companies that develop low cost original products and services, as well as new business models to face such social issues (Cuervo Cazurra et al. 2019).

- Industry: Competition is a traditional driver of innovation. Growing and more sophisticated consumer markets are increasing the production standards and innovation processes of local companies. Subsidiaries of multinationals from developed countries are also an important source of innovation.

- Firm: A number of factors, such as size, ownership, or degree of internationalisation can influence a firm's innovation capabilities. Studies on multilatinas have confirmed that companies with higher commitment to innovation (R\&D expenses, as a percentage of total expenses) tend to be present in more international markets.

- Innovation systems: Many elements of innovation ecosystems (research institutions, technology parks, universities, investors and risk capital) are far more constrained in Latin America than in developed countries. Brazil has the most mature innovation ecosystem in the region and as such has one of the most successful high-tech entrepreneurial movements in Latin America. Recently, Mexico has made significant progress in promoting innovation and startups through a number of regulations and reforms. Colombia and Argentina lack large-scale innovation initiatives but have a vibrant entrepreneurial community finding opportunities through new business model creation.

\section{Types of Innovation in and from Latin America}

- Technology-driven and R\&D-based innovation: Such innovation is developed by the private sector in Latin America. Examples of innovative firms include Brazil's Marcopolo (5th largest bus maker in the world) and Mexico's Cemex (operations in more than 50 countries). Internationalization is a key driver of innovation for multilatinas. Accessing knowledge from R\&D subsidiaries in developed countries has been an integral part of their competitive strategy (Oliveira \& Borini, 2012). Some successful examples include: Brazil's Sabo, an auto parts producer that acquired the German company Kaco to increase its $\mathrm{R} \& \mathrm{D}$ competence; Petrobras, which has developed sophisticated technology for deep water oil drilling; and the Chilean Sigdokopper, which acquired the Belgian Maggoteux, obtaining expertise in solutions for high abrasion industries. Governments also play a significant role. Local governments manage innovation labs and research institutions, such as the Brazilian Agricultural Research Corporation (EMBRAPA), as well as state-owned companies (e.g., Brazil's Petrobras and Argentina's Invap). Foreign subsidiaries of DMNEs have also done R\&D in Latin America. Examples include General Electric, Roche, L'Oréal, Eaton, Siemens, Microsoft, IBM, and Ford in Brazil; Sony, Samsung, LG Electronics, HP, IBM, Siemens, and Motorola in Mexico, and even P\&G in Venezuela.

- Process and organizational innovation: Economic growth, combined with unstable local environments in Latin America have led many companies to develop new organizational processes to deliver products and services. For example, 
weak institutional environments have prompted companies to servitize (adding innovative services to the product offer), thereby creating development opportunities in the service sector. This particular environment has also enabled human resource management to link policies and practices between strategic human resources and the innovation capacity of companies.

- Business model innovation: There has been a dramatic increase of companies in Latin America using digital technology to implement business model innovations in a diversity of businesses, such as internet platforms, digital games, digital solutions, and digital content. Some Latin American examples include Brazil's Nubank (fintech), Argentina's Etermax (digital games), Satellogic (satellites), and Globant (digital solutions) (Cahen \& Oliveira Jr., 2018).

- Frugal innovation: Innovation based on cost-effectiveness involves redesigning and new products development using fewer resources and new production processes. For instance, the Brazilian unicorn PagSeguro created a payment machine called Moderninha, which has no paper reel, rendering the whole process cheaper than the usual payment machines.

\section{Innovation Outcomes in Latin America}

Measuring the outcomes of innovation can be very challenging. Still, some relevant indicators are available. For instance, the Global Innovation Index 2018 includes in its innovation output sub-index ${ }^{1}$ variables related to knowledge, technology and creative outputs. Latin America does not rank high, especially if one considers the size of some of its economies. Brazil and Mexico (ninth and fifteenth largest economies in the world) were ranked respectively $64^{\text {th }}$ and $56^{\text {th }}$ in 2018 . Chile led the region in the GII rankings at $47^{\text {th }}$, while Costa Rica and Colombia were identified as innovation achievers.

Still, traditional and alternative types of innovation are bringing prosperity that transcends economic growth as it reduces inequality and contributes to peace and social stability. Such outcomes are much more difficult to measure, however. Social innovation, including peacebuilding, has ranked high on the agenda of the largest Latin American multinationals. For example Postobon, the largest soft drinks company in Colombia, incorporated into its supply chain farmers and ex-combatants who grow fruits in conflict-affected areas with the goal of maximizing the shared value for the firm and the community (Andonova \& García, 2018).

\section{The Need to Study and Recognize Latin America Innovation Initiatives}

The discussion on innovation in emerging markets is still incipient. Most studies on innovation and R\&D internationaliza- tion focus on a small number of emerging markets, especially in Asia and in particular China (Wan et al., 2015), while only a few studies highlight the innovation and R\&D internationalization of Latin American companies.

Most Latin American companies besides the largest multilatinas face technological and capability gaps, and struggle to achieve international standards. Innovation in Latin American companies is often of a type that does not fit the traditional high-tech, R\&D-based models and is too often overlooked by scholars. This traditional approach does not account for harder-to-measure, more dispersed and even informal types of innovative activities (e.g., business model, organizational or social innovation, among others) common among Latin American companies and many other emerging markets. More research needs to be done to unveil and promote these innovation activities as a way forward for the region.

\section{References}

Amann, E., \& Cantwell, J. (Eds). 2012. Innovative firms in emerging market countries. Oxford: Oxford University Press.

Andonova, V., \& Losada, M. 2017. Multilatinas: Strategies for internationalization. Cambridge: Cambridge University Press.

Andonova, V., \& García, J. 2018. How can EMNCs enhance their global competitive advantage by engaging in domestic peacebuilding? The case of Colombia. Transnational Corporations Review, 10(4): 370-385.

Cahen, F., Casanova, L., \& Miroux, A. 2019. From copycat to leaders: Innovation from emerging markets. Cambridge: Cambridge University Press.

Cahen, F., \& Oliveira Jr, M. M. 2018. Digital transformation in emerging markets: strategies and internationalization of digital companies from Latin America. In: L. Casanova \& A. Miroux (Eds.), Emerging market multinationals report (EMR), Emerging Markets Institute, S.C. Johnson School of Management, Cornell University. Available at: https://www.johnson.cornell.edu/Portals/32/EMI\%20 Docu/EMR/EMR2018 V3.pdf.

Casanova, L. 2009. Global Latinas: Latin America's emerging multinationals. New York: Palgrave Macmillan.

Casanova, L. \& Miroux, A. 2018. Emerging Market Multinationals Report: Emerging Markets Reshaping Globalization. Emerging Markets Institute. S.C. Johnson School of Management, Cornell University. ISBN: 978-1-7328042-1-0. Available at: https://www. johnson.cornell.edu/Portals/32/EMI\%20Docu/EMR/EMR2018_ V3.pdf.

Cuervo-Cazurra, A., Carneiro, J., Finchelstein, D., Durán, P., Gonzalez-Perez, M. A., Montoya, M. A., Borda, A., Fleury, M. T. \& Newburry, W. 2019. Uncommoditizing strategies by emerging market firms. Multinational Business Review, forthcoming.

Finchelstein, D. 2017. The role of the State in the internationalization of Latin American firms. Journal of World Business, 52(4): 578-590. 
Oliveira Jr., M., \& Borini, F. 2012. The role of subsidiaries from

emerging economies-A survey involving the largest Brazilian multinationals. Thunderbird International Business Review, 54(3), 361-371.

Oliveira Jr., M; Cahen, F \& Borini, F. 2019 (Forthcoming). Startups and innovation ecosystems in emerging markets. A Brazilian perspective. New York: Palgrave Macmillan.

Wan, F., Williamson, P. J., \& Yin, E. 2015. Antecedents and implications of disruptive innovation: Evidence from China. Technovation, 39: 94-104

Emerging Multinationals Research Network (EMRN)

Lourdes Casanova (Ic683@cornell.edu) is Senior Lecturer and Director of the Emerging Markets Institute at Cornell University. In 2014 and 2015, she was one of the 50 Most Influential Iberoamerican Intellectuals, and in 2017, one of the 30 Most Influential Iberoamerican Women Intellectuals by Esglobal. Co-author: Entrepreneurship and the Finance of Innovation in Emerging Markets 2017. Co-Author with A. Miroux: Emerging Market Multinationals Report 2018, 2017, 2016. Co-author: The Political Economy of an Emerging Global Power 2014, author 'Global Latinas: Latin America's emerging multinationals' 2009.

Fernanda Cahen (fribeiro@fei.edu.br) is Visiting Researcher at University of Southern California - Marshall School of Business and Assistant Professor of management at Centro Universitario FEl, Brazil. She received her PhD from University of Sao Paulo in Business Administration and was a Post-doctoral fellow at Kelley School of Business - Indiana University. She specializes in international entrepreneurship with focus on strategy and innovation of high tech and digital new ventures.

Anne Miroux (am2449@cornell.edu) is Faculty Fellow at the Emerging Markets Institute, Cornell University and former Director of the Technology Division in the United Nations Conference on Trade and Development (UNCTAD). She graduated from HEC-Paris and holds a PHd from University of Parisl-Sorbonne. Her areas of work included developing country debt, FDI and TNCs, and technology and innovation policies. For several years she led the World Investment Report (WIR). Her current research area is emerging market multinationals.

Diego Finchelstein (dfinchelstein@udesa.edu.ar) is Assistant Professor at Universidad de San Andrés (Argentina) and a researcher at the Argentine national research agency (CONICET). He holds a PhD from Northwestern University. His main area of research is connected the relation between institutions, state actions and internationalization. Finchelstein is an active member of the Emerging Markets Research Network and is also part of the executive board of the Latin America and Caribbean chapter of the Academy of International Business.

\section{Endnote}

1 The Global Innovation Index (GII) is composed of an "innovation input" sub-index and "innovation output" sub-index. See Cornell, INSEAD, and WIPO (2018) Global Innovation Index 2018 Report.
Anabella Davila (anabella.davila@tec.mx) is Professor of Management and Strategic Human Resource Management and the leader of the research group: Strategy and Management in Emerging Economies at EGADE Business School, Tecnologico de Monterrey. She holds a Ph. D. from The Pennsylvania State University. Her current research interest is the social dimension of human resource management with a focus on human development, sustainability and competitiveness. She is a member of the Mexican Researchers System of CONACYT Tier II.

Juana García Duque (juanagarcia@uniandes.edu.co) is Professor at the Business School at Universidad de los Andes, Colombia. Her research includes international cooperation and private sector in peacebuilding process in Colombia and emerging countries. She is leading the work with the Colombian Agency for the Reintegration of Ex-combatants, documenting the process and the engagement of multiple society stakeholders, including business organizations. She has been working in new blended courses and MOOCs for education in Emerging Markets.

Veneta Andonova (veneta.andonova@gmail.com) is Associate Professor of Business Strategy at Universidad de los Andes School of Management, Colombia. She obtained her PhD degree from Universitat Pompeu Fabra, Spain. Her research stands at the intersection of business strategy, entrepreneurship and economic development in the context of emerging and transition economies. Her most recent books are on the internationalization of Latin American corporations, the multilatinas, and on the birth of entrepreneurial ecosystems in unexpected places.

Moacir de Miranda Oliveira Jr. (mirandaoliveira@usp.br) is Full Professor and Head of the Business Administration Department at USP - University of São Paulo. He is the director for Latin America of GLORAD (Center for Global R\&D and Innovation), Chief Editor of Innovation \& Management Review, and part of the Global Steering Committee of Emerging Markets Institute - Cornell University. His research interests include startups and innovation ecosystems in emerging markets. 